DEMOGRAPHIC RESEARCH

VOLUME 33, ARTICLE 34, PAGES 985-1014

PUBLISHED 10 NOVEMBER 2015

http://www.demographic-research.org/Volumes/Vol33/34/

DOI: 10.4054/DemRes.2015.33.34

Research Article

First conjugal union and religion: Signs contrary to the Second Demographic Transition in Brazil?

\author{
Ana Paula Verona \\ Claudio Santiago Dias Jr \\ Dimitri Fazito \\ Paula Miranda-Ribeiro \\ (C) 2015 Verona et al. \\ This open-access work is published under the terms of the Creative Commons \\ Attribution NonCommercial License 2.0 Germany, which permits use, \\ reproduction \& distribution in any medium for non-commercial purposes, \\ provided the original author(s) and source are given credit. \\ See http://creativecommons.org/licenses/by-nc/2.0/de/
}




\section{Table of Contents}

1 Introduction 986

$2 \quad$ Entry into marital union and type of union in Brazil 987

$3 \quad$ Religious changes in Brazil 989

$4 \quad$ The mechanisms of religion's influence on family formation 991

$5 \quad$ Hypotheses 992

$6 \quad$ Materials and methods 993

$7 \quad$ Results 997

$\begin{array}{lll}7.1 & \text { Descriptive results } & 997\end{array}$

$\begin{array}{llr}7.2 & \text { Multivariate results } & 1000\end{array}$

$\begin{array}{ll}7.3 & \text { Attempting a causal inference } \\ \end{array}$

$8 \quad$ Summary and discussion $\quad 1007$

9 Acknowledgements 1009

$\begin{array}{ll}\text { References } & 1010\end{array}$ 


\title{
First conjugal union and religion: Signs contrary to the Second Demographic Transition in Brazil?
}

\author{
Ana Paula Verona ${ }^{1}$ \\ Claudio Santiago Dias $\mathbf{J r}^{2}$ \\ Dimitri Fazito ${ }^{3}$ \\ Paula Miranda-Ribeiro ${ }^{4}$
}

\begin{abstract}
BACKGROUND

Two of main characteristics of the Latin American conjugal union pattern are the early entry into first union and the increasing proportion of informal unions. These features have been associated, respectively, with the strong presence and role of family ties in promoting economic and social stability and with changing attitudes in the family, ethnic, and religious spheres.
\end{abstract}

\section{OBJECTIVE}

The objective of this study is to examine the association of religion with entry into first conjugal union and type of first union (formal or informal) among women aged 20-29 years old in Brazil.

\section{METHODS}

Data from the 2006 National Survey on Demography and Health and logistic regression models were used. Considering the cross-sectional nature of the data, an attempt was made to infer the causal direction of the relationship between religion and first conjugal union and type of union.

\section{RESULTS}

The main results show that Evangelical women (Missionary and Pentecostal), when compared to Catholics, have much higher odds of being in a union for the first time (suggesting early age at the time of union) and of engaging in a formal union. This result contradicts the common finding observed in Latin America that women in early unions prefer an informal union.

\footnotetext{
${ }^{1}$ Cedeplar, Universidade Federal de Minas Gerais (UFMG), Brazil. E-Mail: anapaulaverona@gmail.com.

${ }^{2}$ Universidade Federal de Minas Gerais (UFMG), Brazil.

${ }^{3}$ Universidade Federal de Minas Gerais (UFMG), Brazil.

${ }^{4}$ Cedeplar, Universidade Federal de Minas Gerais (UFMG), Brazil.
} 
Verona et al.: First conjugal union and religion

\section{CONCLUSIONS}

The results contribute to the discussion on potential signs of the Second Demographic Transition (SDT) in Brazil. The two features observed among Evangelical women, early and formal marriage, are aspects that inhibit or delay the diffusion of the conjugal union pattern suggested by this approach.

\section{Introduction}

The conjugal union pattern in Latin America is marked by the following two characteristics: early entry into first union and the increasing proportion of informal unions (Rosero-Bixby 1996; Vignoli 2005; Esteve, Lesthaeghe, and Lopez-Gay 2012; Esteve, López-Ruiz, and Spijker 2013; Covre-Sussai et al. 2015). These two aspects are connected, as countries with an earlier age of entry into first union tend to also have a higher proportion of informal marriages (Castro Martin 2002; Fussell and Palloni 2004).

The early age of entry into the process of Latin American family formation has been explained by, among other reasons, the strong presence and role of family ties in promoting economic and social stability. This approach emphasizes that the family is essential for livelihood and the accumulation of resources that is commonly triggered in contexts of precarious government intervention and regional crises. Access to resources occurs through family networks, which helps to explain the preference for early conjugal union (Acosta 2003; Fussell and Palloni 2004).

Moreover, the increase in the proportion of informal unions has recently been associated with the potential secularization process observed in Latin America. In this sense, shifts in attitudes in the family, ethnic, and religious spheres might help to explain the cohabitation boom (as termed by Esteve, Lesthaeghe, and Lopez-Gay 2012) in Latin America in recent decades.

The case of Brazil is interesting because this country has been experiencing religious changes that might both corroborate and challenge the explanations mentioned above. The Evangelical movement, for instance, is growing significantly in the country, and it addresses topics and issues concerning marriage and family formation. In general, this approach is performed conservatively and explicitly. In addition to valuing (early) marriage, the Evangelical movement emphasizes that marriage should be formal and both blessed by the church and officially confirmed in the civil registry.

Using data from the PNDS 2006 (Pesquisa Nacional de Demografia e Saúde da Mulher e da Criança - National Survey on Demography and Health of Women and Children), the initial goal of the current study is to examine the association between 
religion and women's entry into first union in Brazil. Next, specifically considering women who were in their first conjugal union at the time of the survey, this study investigates the association between religion and type of first union (whether formal or informal). This study examines women aged 20 to 29 years old in Brazil because the majority of Brazilian women in this age group had already experienced their first union in 2006 (PNDS 2009). Notably, unlike most studies on marriage in Brazil, the results of the current study enable the examination of characteristics of the marital regime while taking into consideration the initial trajectory of women's conjugal life.

The results of this study contribute to the discussion on potential signs of the Second Demographic Transition (SDT) in Brazil (and the rest of Latin America). Among other aspects, the SDT diagnosis requires the presence of a rise in age at first marriage and a rise in pre-marital cohabitation among high-educated groups (Lestheaghe 2010). With the significant growth of Evangelicals in Brazil and this religious segment's likely preference for early and formal marriage, the conjugal pattern suggested by the SDT is even more distant.

Finally, it is important to emphasize that in the scientific literature, studies on associations between religion and characteristics of family formation using Brazilian demographic data are rare or even non-existent. Thus, the current study seeks to help fill this gap.

\section{Entry into marital union and type of union in Brazil}

First union in Latin America is earlier than expected for a region that is considered as middle income and medium-low fertility. As in the other countries in this continent, Brazilian data demonstrate a stable and earlier than expected pattern of age at union. Between 1960 and 2000, Brazilian women's average age at union rose from 22.2 to 22.7 years (Fussell and Paloni 2004). In the most recent census in 2010 the average age was 23.1 years. Furthermore, the proportion of consensual unions in the country has grown substantially. For example, the proportion of women between 25 and 29 years in a consensual union increased from 7.2\% to 50.0\% between 1970 and 2010 in Brazil (Esteve et al. 2012; Covre-Sussai et al. 2015).

Despite great social transformations in Latin America in recent decades (e.g., the significant increase in female schooling), the timing of union formation has remained stable and early in this region (Rosero-Bixby 1996; Heaton, Forste, and Otterstrom 2002; Fussell and Paloni 2004). Esteve, López-Ruiz, and Spijker (2013) recently examined this contradiction in a study of women between 15 and 50 years old in eight Latin American countries between 1970 and 2000. The authors test the hypothesis that the stability of the timing of union formation in the context of educational expansion is 
due to compensatory changes among groups with different levels of education. In other words, the postponement of union formation that is expected with educational expansion is counterbalanced by the volume of earlier unions among the less-educated women in younger cohorts. The authors highlighted that, when observed, the stable or earlier timing of union formation occurred mainly through the increased volume of informal unions. This result confirms the association between early age at first union and the preference for an informal union.

Another hypothesis has been proposed to explain the maintenance of early union formation in Latin America. Fussell and Paloni (2004) argued that the persistence of this conjugal regime during intense political, social, and economic changes in Latin America is the result of the role of union (and family) in promoting economic and social stability. These authors note that the early pattern of Latin American family formation comprises strong family ties, both intra- and intergenerational, which prevail in all social classes. These family support networks are viewed as strategies (Acosta 2003) that are traditionally utilized in times of crisis, uncertainty, and absent or poor government intervention. Thus, conjugal union is considered to be an important cultural and social institution, through which the pattern of family formation is reproduced in Latin America ${ }^{5}$ (Fussell and Paloni 2004).

The informal union, which has existed since Brazil was established, has recently undergone a very notable growth there and elsewhere in Latin America (Esteve, Lesthaeghe, and Lopez-Gay 2012). In Brazil, informal unions are often considered a less expensive alternative to formal marriage. Thus this type of union is preferred among strata with lower education and income levels (Rosero-Bixby 1996; Vignoli 2005). However, important changes have been observed (Castro Martin 2002; García and Rojas 2002). For example, in a recent study on the association between informal unions and education levels in Latin America, Esteve, Lesthaeghe, and Lopez-Gay (2012) confirmed the existence of a new pattern, characterized by an increase in the prevalence of cohabitation at all education levels but especially at medium and high levels.

In addition to considering economic factors, these authors analyzed how ideational changes related to religious, ethnic, and family issues might be associated with the rise in cohabitation in Latin American countries. Esteve, Lesthaeghe, and Lopez-Gay (2012) argued that the greater tolerance in a more secular context might be associated with the cohabitation boom in Latin America. Evidence of this association suggests the possible

\footnotetext{
${ }^{5}$ It is important to mention that other determinants, which this approach underestimates, can help to explain early union in Latin America. These determinants are linked to: i) the reproduction of poverty and social and gender inequality; ii) the shortages of job and education opportunities for adolescents and young people; iii) the lack of sex education and access to sexual and reproductive health services for adolescent and young people; iv) early fertility, which may encourage early union.
} 
convergence of at least some sub-groups of Latin-American populations to the pattern of the SDT.

Interestingly, in regards to changing opinion concerning the role that religion plays in family issues, Brazil does not exhibit indicators of a growth in secularization. For example, in Brazil between 1991 and 2006 an increase was noted in the proportion of the population that believed that religion plays an important role in decisions concerning family issues (Esteve, Lesthaeghe, and Lopez-Gay 2012).

In this context, religion may influence decisions about union formation in Brazil. Some churches in Brazil strongly emphasize aspects of the family sphere, such as the timing and type of union, premarital sex, homosexuality, partner choice, abortion, reproduction, and divorce. However, few studies have examined religion as an explanatory variable of such events in Brazil. This gap widens when considering the recent changes in the Brazilian religious context, especially the growing number and influence of Evangelical churches.

\section{Religious changes in Brazil}

In recent decades Brazil has experienced striking changes in its religious landscape. An important change is the end of the Catholic hegemony in the country. The Brazilian census of 1950 revealed that $93.7 \%$ of Brazilians declared themselves as Catholics. This proportion had significantly decreased to $64.6 \%$ by 2010 . Moreover, the last intercensal period witnessed the first decrease in the absolute number of Catholics in the country, from 124,980,000 people in 2000 to 123,280,000 in 2010 (Alves, Barros, and Cavenaghi 2012).

Catholicism, which was brought to Brazil by the Portuguese in 1500, was often considered a flexible religion that required little from the faithful (Bruneau 1982). The traditional Catholic, who remains the majority in Brazil, often practices religious syncretism and shows low participation in church activities (Pierucci and Prandi 2000). Many of these Catholics only attend Mass for rites of passage such as baptisms and weddings and on special occasions such as Christmas or Holy Days.

An exception to this type of behavior is observed among supporters of the Catholic Charismatic Renewal (CCR). This movement, of U.S. origin, arrived in Brazil in the late 1960s. Similarly to Evangelical Pentecostalism, CCR emphasizes the gifts of the Holy Spirit and demands an orderly behavior and lifestyle, especially with regard to matters of family and sexuality (Cleary 2007; Chesnut 2003; Pierucci and Prandi $2000)^{6}$.

\footnotetext{
${ }^{6}$ Although multiple studies have stated the demographic growth of this movement, it is not possible to determine the proportion of Catholics who are members of the CCR through the Brazilian census.
} 
Verona et al.: First conjugal union and religion

An additional significant recent change in the Brazilian religious context is the growth in the number of Evangelicals, who represented only $3.4 \%$ of the population in 1950. Sixty years later, $22.2 \%$ of Brazilians declared themselves members of this religious group. Between 2000 and 2010 an increase of 16 million Evangelicals was observed in Brazil. The recent expansion of Evangelicals has also reached other Latin American countries. The most recent Pew Research Center survey conducted in 2014 in 18 countries and one U.S. territory (Puerto Rico) across Latin America and the Caribbean found that the countries with the largest proportions of Evangelicals include Honduras and Guatemala (41\% each), Nicaragua (40\%), El Salvador (36\%), Brazil (26\%), and Costa Rica (25\%). Overall, nearly 1 in 5 Latin Americans (19\%) describe themselves as Evangelicals. ${ }^{7}$

Evangelicals can be divided into three major segments: Missionary Evangelicals, Pentecostals ${ }^{8}$, and nondenominational Evangelicals. ${ }^{9}$ They represented, respectively, $18.2 \%, 60.0 \%$, and $21.8 \%$ of the total group of Evangelicals in Brazil in 2010. The Missionary Evangelicals are primarily affiliated with the Baptist, Lutheran, and Presbyterian churches. Pentecostals are mainly represented by members of the Assembly of God, Christian Congregation of Brazil, God is Love, and the Universal Church of the Kingdom of God. The main difference between these two groups is the Pentecostal emphasis on the gifts of the Holy Spirit.

Pentecostalism emerged and grew among the poorest strata of the population, and it remains the religious group with the lowest education and income levels in the country (Alves, Barros, and Cavenaghi 2012). Even so, some Pentecostals have reached intermediate or high levels of education. According to the 2010 Brazilian census, 35.6\% of Pentecostal women age 25-29 had completed secondary education and $14.4 \%$ had completed some college (results not shown). Followers of other Evangelical churches are more educated than Pentecostals. Among women aged 25-29, 33.8\% of Missionary Evangelicals and $24.2 \%$ of nondenominational Evangelicals had completed some college in $2010^{10}$ (results not shown).

Currently, the growth in the number of Evangelicals is significant among young people, those who identified themselves as brown or black, and residents of

\footnotetext{
${ }^{7}$ Source: http://www.pewforum.org/2014/11/13/religion-in-latin-america/

${ }^{8}$ Of North American origin, Pentecostalism arrived at the beginning of the 20th century in Belém, the capital of the state of Pará. This state is located in the Amazon region, where the country's first Assembly of God church was built. A slight growth in Pentecostalism began to be observed in the second half of the 20th century, when receipt of the gift of divine healing began to be emphasized and associated with a transformation of the behavior and lifestyle of the faithful.

${ }^{9}$ In this segment, individuals self-reported themselves as evangelicals with no institutional affiliation. The percentage of Nondenominational Evangelicals rapidly increased between 2000 and 2010 in Brazil. Mariano (2013) suggests some explanations for this phenomenon.

${ }^{10}$ Overall, $19.7 \%$ of Evangelical women age 25-29 had more than complete secondary education in Brazil in 2010.
} 
metropolitan regions. This is not surprising, because these parts of the population have received increasing attention and space within Pentecostal churches. These churches often provide an area for socialization and learning and offer various activities in which a young supporter can participate (Verona 2010, 2011). Moreover, the increase of Evangelicals is concentrated in specific regions. Using data from the 2010 Brazilian demographic census, Alves, Barros, and Cavenaghi (2012) found that the largest proportions of Evangelicals reside in the north (28.5\%), central-west (26.8\%), and southeast (24.6\%), while the smallest proportions live in the northeast (16.4\%), and south (20.2\%). Unlike in traditional Catholicism, Evangelical churches in Brazil explicitly present rules of conduct that must be followed by the faithful. Moreover, they successfully spread such information (through television and virtual media, for example) and often generate feelings of belonging in the religious group. According to McQuillan (2004), these characteristics are fundamental for a religion to influence the life of its followers.

\section{The mechanisms of religion's influence on family formation}

How can religion affect entry into first union and the choice of type of union? The following two mechanisms of influence are especially important in answering this question: moral guidelines and intensification of family ties. Considering the first mechanism, religion can emphasize teachings and doctrines of moral order within the family sphere, emphasizing what is right or wrong and what is allowed and proscribed. Several studies have tested the hypothesis that individuals who regularly attend churches that emphasize the sacredness of marriage and promote teachings on the subject show lower odds of experiencing certain types of behavior, such as informal marriage, childbearing during adolescence, divorce, or extramarital relations (Hill, Cleland, and Ali 2004; McKinnon, Potter, and Garrard-Burnett 2008; Eggebeen and Dew 2009; Vaaler, Ellison, and Powers 2009; Ogland and Verona 2011; Verona and Dias Jr 2012).

Evangelical churches in Brazil have conservative attitudes towards the family and sexuality. They provide clear teachings concerning practices related to dating, sexual initiation, and marriage (Mariz 1994; Burdick 1993; Chesnut 2003). Teachings that value marriage are common, and state that "it is not God's plan for you [the faithful] to be alone, you [the faithful] should marry" (Verona 2010: 114). These churches also argue that sex before marriage is a sin and should therefore be avoided (Burdick 1993; Mariz 1994; Verona and Regnerus 2014). Some studies suggest a connection between this argument and early marriage. Verona (2010: 116), for example, mentions that teachings in Pentecostal churches in Brazil emphasize that "if a young person isn't 
managing to contain his or her sexual desire, he or she should marry”. Considering these guidelines, Evangelical adolescents and youth may feel encouraged to marry (earlier) to avoid premarital sexual practice. Evangelical churches also commonly address the type of union that the faithful choose. These churches strongly encourage official and formal unions, performed both in the civil registry and in a religious ceremony in the church. They even encourage the formalization of the union of those who convert to Pentecostalism and are living consensually (Verona 2010).

In addition to moral guidelines, religion may exert an influence through the intensification of family ties, which may contribute, for example, to parental supervision and involvement in children's wellbeing and decisions (Smith 2003; Wilcox et al. 2001; DeMaris, Mahoney, and Pargament 2011). The intensification of family ties through religion can occur in several ways, such as through teaching rules that value a relationship of love, respect, and compromise between parents and children (Smith 2003). Furthermore, religion can provide opportunities for outreach and interaction between parents and children, such as participation in activities organized especially for the family, worship, and group meetings (Wilcox et al. 2001).

Evangelical churches in Brazil offer such teachings and opportunities for parental interaction and involvement in their children's lives. Several reports from fieldwork have emphasized that Pentecostal parents (from the Assembly of God) closely monitor the lives and relationships of their daughters. For example, these parents disapprove of long courtships and marriage to people of a different religion (Burdick 1993; Mariz 1994; Verona 2010).

The current study assumes that conservative moral guidelines and strong family ties, as constructed and emphasized by some churches in Brazil, may be mechanisms through which religion affects both the timing of the first union and the type of union chosen by young women in Brazil.

\section{Hypotheses}

Figure 1 presents the research hypotheses of this study. Hypothesis 1, for instance, states that Missionary Evangelical and Pentecostal young women will show a higher odds of being in a union for the first time than Catholics. 
Figure 1: Summary of hypotheses

\begin{tabular}{|l|l|l|}
\hline \multicolumn{1}{|c|}{ Union Formation } & $\begin{array}{l}\text { A higher odds of being } \\
\text { in a union for the first } \\
\text { time }\end{array}$ & $\begin{array}{l}\text { A higher odds of } \\
\text { being in a formal } \\
\text { union }\end{array}$ \\
\hline $\begin{array}{l}\text { Missionary Evangelical and Pentecostal } \\
\text { young women compared to Catholics (the } \\
\text { reference group). }\end{array}$ & Hypothesis 1 & Hypothesis 4 \\
\hline $\begin{array}{l}\text { Young women who attend church regularly } \\
\text { compared to those who rarely or never } \\
\text { attend church (the reference group). }\end{array}$ & Hypothesis 2 & Hypothesis 5 \\
\hline $\begin{array}{l}\text { Missionary Evangelical and Pentecostal } \\
\text { young women with high attendance at } \\
\text { worship services compared to Catholics with } \\
\text { high attendance (the reference group). }\end{array}$ & Hypothesis 3 & Hypothesis 6 \\
\hline $\begin{array}{l}\text { The associations described in hypotheses } \\
1 \text { and 4 will be stronger when only analyzing } \\
\text { women who report their current religion as } \\
\text { being the same in which they were raised. }\end{array}$ & \multicolumn{1}{|c|}{ Hypothesis 7 } \\
\hline
\end{tabular}

\section{Materials and methods}

The current study utilized nationally representative cross-sectional data gathered from the 2006 National Survey on Demography and Health of Women and Children (Pesquisa Nacional de Demografia e Saúde da Mulher e da Criança - PNDS). This study was conducted by the Brazilian Center of Analysis and Planning (Centro Brasileiro de Análise e Planejamento - CEBRAP) and financed by the Ministry of Health. The PNDS 2006 is a complex probabilistic sample, stratified into two stages as follows: primary units composed of census sectors and secondary units formed of household units. Therefore it is necessary to specify their respective weights and sampling units (Cavenaghi 2009a). The information required for this specification is available in the stratum (ten units) and conglomerate (1,088 sectors) variables. For the sample weights, the expansion factor of the analyzed group was used (weight of the eligible woman in the household). In STATA software, version 10, these specifications 
Verona et al.: First conjugal union and religion

can be performed via the command "svyset", which produces estimates for standard errors and statistical tests corrected for the complexity of the sample. All descriptive and statistical analyses presented in the current paper were corrected by this command.

\subsection{Religion variables}

The PNDS 2006 contains three questions on religious involvement: current religious affiliation, religious affiliation in which a person was raised, and attendance at worship services or Mass. The PNDS 2006 ranks religious affiliation (current, and religion in which a person was raised) into the following six groups: 1) Catholic, 2) Missionary Evangelical, 3) Pentecostal, 4) Spiritualist, 5) Afro-Brazilian religions, and 6) other religions. In this study, this variable was re-categorized as follows: (1) Catholic (reference group), 2) Missionary Evangelical, 3) Pentecostal and 4) other religions. Finally, the religion variable also includes a fifth category for those who reported no religious affiliation.

The variable of attendance at worship services or Mass is classified into five groups: attends worship services or Mass 1) more than once per week, 2) once per week, 3) less than once per week, 4) less than once per month, and 5) never (reference group). To facilitate the interpretation of the results and due to the high attendance at worship services or Mass, groups 1) and 2) were regrouped into a single group.

Current denomination and religious attendance were entered into the models separately because a strong association was observed between these variables (see Table 1). To avoid multicollinearity in the statistical models, six dichotomous variables were created to represent mutually exclusive interactions between three religious affiliations and two categories of attendance at worship services and Mass (women who attend worship services or Mass at least once per week - high frequency - and women who attend less than once per week - low frequency). The following six variables were created: 1) Catholics who attend worship services or Mass at least once weekly (reference group), 2) Catholics who attend less than once per week, 3) Missionary Evangelicals who attend worship services once or more per week, 4) Missionary Evangelicals attending less than once per week, 5) Pentecostals who attend services at least weekly, and 6) Pentecostals attending less than every week.

\subsection{Dependent variables and statistical models}

We used a subsample of the PNDS 2006 that included women between 20 and 29 years of age. This age group corresponds to 4,943 of the total 15,575 interviewed women 
between 15 and 49 years. Brazilian women between 20 and 29 years old were chosen because many of them had experienced their first union by this stage. Furthermore, when analyzing women in this age group it is expected that the union is relatively recent and that a considerable proportion of the women have not changed religious affiliation (and attendance) since union formation.

Three variables on conjugal status were employed in the PNDS 2006. The first variable asks if the woman is currently married or in a union. The following four answer options are offered: 1) yes, formally married, 2) yes, in an informal union with a man, 3) yes, in an informal union with a woman, and 4) not in a union. The second variable asks whether the woman has been married or in a union in the past. Again, four answers were offered, as follows: 1) yes, was formally married, 2) yes, was in an informal union with a man, 3) yes, was in an informal union with a woman, and 4) never been in a union. The third variable asks if the woman has been in a union (formal or informally) 1) once or 2) more than once in her lifetime.

Of the 4,943 women between 20 and 29 years of age, eleven reported being currently in a union with a woman. Because of the small proportion of same sex couples in the sample, we excluded them and kept only heterosexual couples in our analysis.

The current study examines women who have experienced their first union compared to those who have never experienced a union. It was necessary to exclude women who were not classified into one of these two groups. Of the 4,932 women between 20 and 29 years of age, 1,408 had never been in a union, 3,073 were in a heterosexual union, and 451 had been in a union in the past but were not currently in a union. The latter group was excluded from the sample.

Of the women who were currently in a union, only those who were in a union for the first time were kept: women currently in a union but who had been in more than one union in their lifetime were excluded $(n=480)$. The final sample of women currently in a first union comprised 2,593 women, while the total who had never been in a union was 1,408 . The final number of the analyzed sample was 4,001 women aged 20 to 29 years, thus enabling an analysis of the odds of a person experiencing a first union. Subsequently, only those women in a union for the first time were analyzed, to demonstrate the association between religion and type of union. Of the 2,593 women in a union for the first time, 1,236 were in a formal union and 1,357 were in an informal union.

Overall, this study employed three sets of logistic regression models. The first set of models (Models 1, 2, and 3) employed the following binary response variable: never in a union (reference category) and in a union for the first time. The second set considered only those who were in a union for the first time (Models 4, 5, and 6), and its binary response variable was as follows: in an informal union (reference category) and in a formal union. The third group of models is presented below. 


\subsection{Difficulty regarding the direction of causality}

Considering the cross-sectional nature of the data used in this study, it is not possible to establish the causal direction of the relationship between religion and the conjugal union variables. In other words, it is not possible to determine whether the first variable influences the second variable or the other way around. One reason for this methodological difficulty is the lack of longitudinal information, especially regarding the woman's religion at the time of union.

However, the PNDS also asks about the religion in which a woman was raised, which may suggest part of her religious trajectory. For example, women who reported the same religion at upbringing as current religion may never have changed religion. This study assumes this hypothesis. Therefore, Models 7 and 8 include women between 20 and 29 who reported the same current religion as religion in which they were raised, allowing a more adequate analysis of the direction of causality between the variables of interest. This part of the study assumes that religion influences the risk and type of union chosen, rather than the reverse direction. The final sample in this analysis consisted of 3,099 women in Model 7 (women who had never been in a union or were in a union for the first time) and 1,970 women in Model 8 (women in a union for the first time).

\subsection{Control variables}

The following covariates were included in the multivariate models: (1) single years of age reported into ten single categories (20 is the reference age category), (2) four categories of color/race: White (reference), Black, Brown and other color; (3) three education levels: $0-4$ years of formal education (reference), 5-8 years, 9 years and over, (4) if a person currently lives in a rural area (reference) or an urban area, and (5) region of residence (northeast is the reference). This study also evaluated the socioeconomic status (SES) of the women's households using a method suggested by the Brazilian Association of Research Companies (Associação Brasileira de Empresa de Pesquisas ABEP). This method employs information about the education level of the head of the household and the following 9 variables of household consumption: number of televisions, DVD players, radios, bathrooms, cars, washing machines, refrigerators, freezers, and domestic workers (Cavenaghi 2009b). The PNDS 2006 gathered this information to calculate the aggregate indicator of SES, which ranges from 0 to 7 (highest consumption level) and is treated as a continuous variable. 


\section{Results}

\subsection{Descriptive results}

Previous research has emphasized substantial differences in religious service attendance between Evangelicals and other religious groups in Brazil. Table 1 confirms this, showing the distribution of religious affiliation of women between 20 and 29 years old (never in a union or in a union for the first time) based on attendance at worship services or Mass in Brazil in 2006. The results confirm that Missionary Evangelicals and Pentecostals attend church more regularly than Catholics. For example, $76.4 \%$ of Pentecostal women attended worship services at least once per week, whereas $31.1 \%$ of Catholics attended Mass with the same frequency. All of the differences shown in Table 1 are significant at $\mathrm{p}<0.001$.

Table 1: Religious affiliation based on attendance at worship services or Mass among women aged 20 to 29 who had never been in a union or were in their first union

\begin{tabular}{lccccr}
\hline & \multicolumn{5}{c}{ Attendance at religious services or Mass } \\
\cline { 2 - 6 } \multicolumn{1}{c}{ Religious affiliation } & Never & $\begin{array}{c}\text { Less than } \\
\text { monthly }\end{array}$ & $\begin{array}{c}\text { Less than } \\
\text { weekly }\end{array}$ & $\begin{array}{c}\text { At least } \\
\text { weekly }\end{array}$ & Total \\
\hline Catholic & 18.0 & 29.0 & 21.9 & 31.1 & 2,584 \\
Missionary Evangelicals & 4.1 & 12.3 & 10.7 & 73.0 & 491 \\
Pentecostal & 2.4 & 6.8 & 14.4 & 76.4 & 404 \\
Other religions & 20.7 & 18.8 & 9.4 & 51.1 & 160 \\
No religion & 68.5 & 23.8 & 4.0 & 3.7 & 362 \\
\hline $\mathrm{N}$ & 683 & 966 & 732 & 1,620 & 4,001 \\
\hline
\end{tabular}

Source: PNDS 2006

Table 2 shows the perceptual distribution of the independent variables for women between 20 and 29 years old who had never been in a union or were in a union for the first time (formally or informally). Among those that were in a first union (62.9\% of the sample), slightly less than half were in a formal union (31.1\%). The remainder of the sample (37.1\% of women) responded that they had never experienced a conjugal union. As women who were in a union for the second (or more) time and those who were not in a union but had been in the past were excluded from the sample, we were able to analyze the odds of a young woman experiencing her first union, considering the type of this union, without the influence of past conjugal behavior. 
Table 2 also shows the differences in conjugal union according to the woman's age. In general, the higher the age, the higher the proportion of women in a union (women aged 24 are an exception in this trend). In addition, formal union was more common among women aged 24 years or older, while the distribution of women in an informal union by age did not follow a trend. Concerning the categories of the color/race variable, a higher proportion of white women (43.1\%) than brown women (29.7\%) had never been in a conjugal union. When considering the type of union, the difference between these two groups was significant.

Considering the education level, most young women who had less than five years of formal education were in a union at the time of the survey (82.8\%), and most of them were informal unions. Conversely, a high proportion of young women with nine or more years of schooling (47.2\%) had never experienced a conjugal union. Furthermore, when entering a union, this group more often preferred a formal union.

In terms of religious affiliation, Pentecostal women had the lowest proportion of those who had never been in a union (29.5\%). This proportion was higher among Catholics (37.2\%) and non-religious women (42.0\%). According to an analysis of the distribution of women in a union based on religious affiliation, almost $43 \%$ of Missionary Evangelical and Pentecostal women and 29.0\% of Catholics were in formal unions. These results, although descriptive, suggest an association between religious affiliation, timing, and type of union.

Interesting differences according to place of residence and region of Brazil were also found. Among women who lived in urban areas, 39.7\% were never in a union. This proportion was $24.0 \%$ among those who lived in rural areas. Among the residents of southeastern Brazil, 44.4\% had never experienced a conjugal union. In the north, this proportion was $28.6 \%$. Notably, the proportion of northern women aged between 20 and 29 who were in a union for the first time and in an informal union was $44.6 \%$. Finally, women who were in an informal union exhibited a much lower average household socioeconomic status (1.81) than the other groups analyzed. This result confirms the previously identified association between informal unions and lower income levels. Finally, it is important to say that all of the differences shown in Table 2 are significant at $\mathrm{p}<0.001$. 
Table 2: $\quad$ Percentage distribution of independent variables among women aged $\mathbf{2 0}$ to $\mathbf{2 9}$ who were never in a union or in a union for the first time (formally or informally)

\begin{tabular}{|c|c|c|c|c|}
\hline \multirow{2}{*}{ Explanatory Variables } & \multirow{2}{*}{ Total sample } & \multirow{2}{*}{$\begin{array}{c}\text { Never in a } \\
\text { union }\end{array}$} & \multicolumn{2}{|c|}{ In a union for the first time } \\
\hline & & & Formal & Informal \\
\hline \multicolumn{5}{|l|}{ Age } \\
\hline 20 & 10.4 & 55.1 & 10.8 & 34.1 \\
\hline 21 & 10.9 & 43.6 & 28.4 & 28.0 \\
\hline 22 & 10.4 & 48.8 & 18.6 & 32.6 \\
\hline 23 & 10.7 & 47.5 & 20.9 & 31.7 \\
\hline 24 & 11.6 & 30.4 & 35.3 & 34.3 \\
\hline 25 & 9.6 & 38.7 & 34.5 & 26.8 \\
\hline 26 & 9.3 & 32.9 & 34.0 & 33.1 \\
\hline 27 & 9.8 & 27.1 & 42.4 & 30.5 \\
\hline 28 & 8.8 & 20.7 & 47.6 & 31.8 \\
\hline 29 & 8.4 & 19.3 & 44.3 & 36.5 \\
\hline \multicolumn{5}{|l|}{ Race } \\
\hline White & 39.6 & 43.1 & 32.9 & 24.0 \\
\hline Black & 10.7 & 38.0 & 23.7 & 38.3 \\
\hline Brown & 42.2 & 29.7 & 32.1 & 38.2 \\
\hline Other color & 7.6 & 45.2 & 26.1 & 28.7 \\
\hline \multicolumn{5}{|l|}{ Years of formal education } \\
\hline 0 to 4 years & 11.5 & 17.2 & 33.0 & 49.8 \\
\hline 5 to 8 years & 24.3 & 20.1 & 30.7 & 49.3 \\
\hline 9 or more & 64.2 & 47.2 & 31.1 & 21.6 \\
\hline \multicolumn{5}{|l|}{ Religious affiliation } \\
\hline Catholic & 59.0 & 37.2 & 29.0 & 33.7 \\
\hline Missionary Evangelical & 13.4 & 32.5 & 42.6 & 24.9 \\
\hline Pentecostal & 12.2 & 29.5 & 42.8 & 27.7 \\
\hline Other religion & 4.4 & 57.3 & 26.4 & 16.4 \\
\hline No religion & 11.0 & 42.0 & 16.5 & 41.5 \\
\hline \multicolumn{5}{|l|}{ Religious attendance } \\
\hline Never & 19.8 & 41.2 & 17.4 & 41.4 \\
\hline$<$ Monthly & 23.0 & 35.2 & 27.6 & 37.2 \\
\hline$<$ Weekly & 17.0 & 28.8 & 34.7 & 36.5 \\
\hline At least weekly & 40.2 & 39.2 & 38.5 & 22.3 \\
\hline \multicolumn{5}{|l|}{ Current residence } \\
\hline Rural & 16.9 & 24.0 & 40.5 & 35.5 \\
\hline Urban & 83.1 & 39.7 & 29.1 & 31.2 \\
\hline Regions & 26.6 & 31.6 & 31.8 & 36.6 \\
\hline Northeast & 7.5 & 28.6 & 26.8 & 44.6 \\
\hline North & 44.4 & 44.4 & 28.9 & 26.7 \\
\hline Southeast & 14.3 & 33.1 & 36.0 & 31.0 \\
\hline South & 7.2 & 29.2 & 35.8 & 35.0 \\
\hline Midwest & 10.4 & 55.1 & 10.8 & 34.1 \\
\hline SES* & $2.47(0.06)$ & $2.76(1.61)$ & $2.39(1.37)$ & $1.81(1.28)$ \\
\hline Total & 100.00 & 37.1 & 31.1 & 31.8 \\
\hline $\mathrm{N}$ & 4,001 & 1,408 & 1,236 & 1,357 \\
\hline
\end{tabular}

Notes: * Mean and standard deviation in parentheses

Source: PNDS 2006 
Verona et al.: First conjugal union and religion

\subsection{Multivariate results}

Table 3 shows the odds of being in a union for the first time (compared to women who had never experienced a conjugal union) among young women aged 20 to 29 years in Brazil in 2006. In general, Table 3 shows that when controlling for other variables, the association between religion (religious affiliation and attendance) and first conjugal union remained strong. Model 1 of Table 3 shows that Evangelicals exhibited a much higher odds of being in a union for the first time in 2006 compared to Catholics, even when controlling for the other explanatory variables. Missionary Evangelicals and Pentecostals, respectively, had 51\% and 59\% greater odds of being in a union for the first time than Catholics, which supports hypothesis 1 of this study. However, the odds of being in a union was statistically significant at $6 \%$ for the Pentecostals. According to the results of Model 2 (Table 3), the odds of being in a union for the first time showed no statistically significant difference according to worship services or Mass attendance. This finding does not support hypothesis 2 of the current study.

Model 3 (Table 3) suggests a strong association between entry into first union and the interaction between religious affiliation and attendance. Specifically, Catholics with low attendance at Mass had a much higher odds of being in a union than Catholics with high attendance $(\mathrm{OR}=1.93 \mathrm{p}<0.05)$. This result partially confirms the findings in Model 1; i.e., the Catholic Church does not promote incentives for young women to marry, even among those who attend church diligently (at least once a week).

Model 3 also shows that Evangelical young women (Missionary and Pentecostal) with high attendance at worship services had a much higher odds of being in a union than Catholics with the same attendance, supporting hypothesis 3. Moreover, Pentecostal women with low attendance at worship services $(\mathrm{OR}=6.02 ; \mathrm{p}<0.05)$ displayed a higher odds of being in a union than Pentecostals who attended services at least once per week $(\mathrm{OR}=2.02 ; \mathrm{p}<0.05)$. One possible explanation for this result is that according to reports from observations in worship services and in-depth interviews, many couples begin to attend church less regularly after marriage (Verona, 2010). It is common for religious leaders to show concern by mentioning this change in the behavior of couples, which is typically associated with a change in the routine of housework and childcare. If this change is common, there should be a concentration of Pentecostals who stopped attending church after marriage. This might also explain the difference in the odds ratio of being in a union among Catholics according to religious attendance (Model 3). However, this hypothesis cannot be tested in the current study due to a lack of information on religious attendance at the time of union. 
Table 3: Odds ratio of being in a union for the first time compared to never having been in a union. Women between 20 and 29 years old in 2006, Brazil

\begin{tabular}{|c|c|c|c|}
\hline Explanatory Variables & Model 1 & Model 2 & Model 3 \\
\hline \multicolumn{4}{|l|}{ Age } \\
\hline 20 & 1.00 & 1.00 & 1.00 \\
\hline 21 & $1.82^{\star *}$ & $1.77^{\star \star}$ & $1.82^{\star \star}$ \\
\hline 22 & 1.47 & 1.39 & 1.42 \\
\hline 23 & $1.57^{\star}$ & 1.48 & 1.50 \\
\hline 24 & $3.18^{* *}$ & $3.19 * *$ & $3.05^{\star \star}$ \\
\hline 25 & 2.41 ** & $2.24^{\star *}$ & $2.38^{\star \star}$ \\
\hline 26 & $2.77^{* *}$ & $2.66^{\star *}$ & $2.69^{\star \star}$ \\
\hline 27 & $4.03^{* *}$ & $3.85^{\star \star}$ & $4.08^{\star \star}$ \\
\hline 28 & $5.73^{\star *}$ & $5.49 * *$ & $5.86^{\star \star}$ \\
\hline 29 & $6.05^{\star *}$ & $5.68^{* *}$ & $6.16^{\star \star}$ \\
\hline \multicolumn{4}{|l|}{ Race } \\
\hline White & 1.00 & 1.00 & 1.00 \\
\hline Black & 0.97 & 1.02 & 0.99 \\
\hline Brown & $1.46^{* *}$ & $1.51^{\star *}$ & $1.46^{\star \star}$ \\
\hline Other color & 0.85 & 0.88 & 0.90 \\
\hline \multicolumn{4}{|l|}{ Years of formal education } \\
\hline 0 to 4 years & 1.00 & 1.00 & 1.00 \\
\hline 5 to 8 years & 1.15 & 1.09 & 1.17 \\
\hline 9 or more & $0.40^{* *}$ & $0.40^{* *}$ & $0.41^{\star \star}$ \\
\hline \multicolumn{4}{|l|}{ Religious affiliation } \\
\hline Catholic & 1.00 & & \\
\hline Missionary Evangelical & $1.51^{\star *}$ & & \\
\hline Pentecostal & $1.59+$ & & \\
\hline Other religion & $0.60^{*}$ & & \\
\hline No religion & 1.11 & & \\
\hline \multicolumn{4}{|l|}{ Religious attendance } \\
\hline Never & & 1.00 & \\
\hline$<$ Monthly & & 1.00 & \\
\hline$<$ Weekly & & 1.33 & \\
\hline At least weekly & & 0.90 & \\
\hline
\end{tabular}


Verona et al.: First conjugal union and religion

Table 3: (Continued)

\begin{tabular}{lccc}
\hline Explanatory Variables & Model 1 & Model 2 & Model 3 \\
\hline Religious denomination by attendance & & & 1.00 \\
Catholics with high Mass attendance & & & $1.93^{\star *}$ \\
Catholics with low Mass attendance & & & $2.73^{\star *}$ \\
Missionary E. with high services attendance & & & $1.70^{\star *}$ \\
Missionary E. with low services attendance & & & $2.02^{\star *}$ \\
Pentecostals with high services attendance & & & $6.02^{\star *}$ \\
Pentecostals with low services attendance & & & 1.21 \\
Other religion & & & $1.74^{\star *}$ \\
No religion & & & \\
Current residence & & 1.00 & 1.00 \\
Rural & 1.00 & 0.74 & 0.74 \\
Urban & $0.72^{\star *}$ & & \\
Regions & & 1.00 & 1.00 \\
Northeast & 1.00 & 1.26 & 1.27 \\
North & 1.18 & 0.94 & 0.87 \\
Southeast & 0.87 & $1.50^{\star *}$ & $1.56^{\star *}$ \\
South & $1.53^{\star *}$ & $1.69^{\star *}$ & $1.73^{\star *}$ \\
Midwest & $1.67^{\star *}$ & $0.83^{\star *}$ & $0.83^{\star *}$ \\
SES & $0.83^{\star *}$ & & \\
\hline $\mathrm{N}$ & 4,001 & &
\end{tabular}

Notes: ${ }^{\star \star}$ p-value $<0.05$; ${ }^{\star} \mathrm{p}$-value $<0.1 ;+\mathrm{p}$-value $=0.06$

Source: PNDS 2006

The results of the other explanatory variables in Table 3 show that age, color/race, education level, region of residence, and household socioeconomic status were statistically associated with the odds of being in a union for the first time among young people aged 20 to 29 years old in Brazil. As expected, older women had higher odds of being in a union, and women with higher education level and those living in households with a higher socioeconomic status had a lower odds. Another interesting result is that brown women had much higher odds of being in a union than white women.

Next, Table 4 shows the results for women between 20 and 29 years old who were in a union for the first time. According to Model 4, the odds of Evangelicals (Missionary and Pentecostal) being in a formal union were much higher (more than double among Pentecostals) than those of Catholics. This result supports the fourth hypothesis of this study. Notably, the group of non-religious women had much lower odds of being in a formal union ( $\mathrm{OR}=0.44 ; \mathrm{p}<0.05)$. Results from Model 5 support our fifth hypothesis: the higher the religious attendance the higher the odds ratios of being in a formal union. 
Last, Model 6 shows interesting results. First, Catholics who rarely attended church had a much lower odds of being in a formal union than Catholics with high attendance at Mass $(\mathrm{OR}=0.49 ; \mathrm{p}<0.05)$. As it is not possible to determine the direction of causality, we consider the following two explanations for this finding: the Catholic Church inhibits informal marriage among young people who attend church more regularly, or some Catholics stop attending Mass weekly after entering an informal union.

Table 4: Odds ratio of being in a formal versus informal union. Women between 20 and 29 years old in 2006, Brazil

\begin{tabular}{|c|c|c|c|}
\hline Explanatory Variables & Model 4 & Model 5 & Model 6 \\
\hline \multicolumn{4}{|l|}{ Age } \\
\hline 20 & 1.00 & 1.00 & 1.00 \\
\hline 21 & $3.53^{\star \star}$ & $3.64^{\star \star}$ & $3.78^{\star \star}$ \\
\hline 22 & $1.92^{\star \star}$ & $2.21^{\star \star}$ & $2.19^{\star \star}$ \\
\hline 23 & $1.81^{*}$ & $1.96^{\star}$ & $2.00^{*}$ \\
\hline 24 & $2.98^{\star \star}$ & $3.44^{\star \star}$ & $3.43^{\star *}$ \\
\hline 25 & $3.63^{\star \star}$ & $3.96 * \star$ & $4.14^{\star \star}$ \\
\hline 26 & $2.92^{\star \star}$ & $3.31^{\star \star}$ & $3.39^{\star *}$ \\
\hline 27 & $4.27^{\star \star}$ & $4.45^{\star \star}$ & $4.68^{\star \star}$ \\
\hline 28 & $4.46^{\star \star}$ & $4.47^{\star \star}$ & $4.75^{\star \star}$ \\
\hline 29 & $3.91^{\star \star}$ & $3.90 * \star$ & $4.26^{\star \star}$ \\
\hline \multicolumn{4}{|l|}{ Race } \\
\hline White & 1.00 & 1.00 & 1.00 \\
\hline Black & $0.51^{\star \star}$ & $0.44^{\star \star}$ & $0.48^{\star \star}$ \\
\hline Brown & $0.68^{\star \star}$ & 0.70 ** & $0.70^{* \star}$ \\
\hline Other color & 0.78 & 0.76 & 0.74 \\
\hline \multicolumn{4}{|l|}{ Years of formal education } \\
\hline 0 to 4 years & 1.00 & 1.00 & 1.00 \\
\hline 5 to 8 years & 1.06 & 1.00 & 1.07 \\
\hline 9 or more & $1.97^{\star \star}$ & 1.99 ** & $2.02^{\star \star}$ \\
\hline \multicolumn{4}{|l|}{ Religious affiliation } \\
\hline Catholic & 1.00 & & \\
\hline Missionary Evangelical & $1.89^{* \star}$ & & \\
\hline Pentecostal & $2.10^{\star \star}$ & & \\
\hline Other religion & 1.13 & & \\
\hline No religion & $0.44^{\star \star}$ & & \\
\hline
\end{tabular}


Verona et al.: First conjugal union and religion

Table 4: (Continued)

\begin{tabular}{|c|c|c|c|}
\hline Explanatory Variables & Model 4 & Model 5 & Model 6 \\
\hline \multicolumn{4}{|l|}{ Religious attendance } \\
\hline Never & & 1.00 & \\
\hline$<$ Monthly & & $1.97^{\star \star}$ & \\
\hline$<$ Weekly & & $2.38^{\star *}$ & \\
\hline At least weekly & & $4.93^{\star *}$ & \\
\hline \multicolumn{4}{|l|}{ Religious denomination by attendance } \\
\hline Catholics with high Mass attendance & & & 1.00 \\
\hline Catholics with low Mass attendance & & & $0.49^{* *}$ \\
\hline Missionary E. with high services attendance & & & 1.38 \\
\hline Missionary E. with low services attendance & & & 0.64 \\
\hline Pentecostals with high services attendance & & & $2.01^{* \star}$ \\
\hline Pentecostals with low services attendance & & & $0.43^{* *}$ \\
\hline Other religion & & & 0.63 \\
\hline No religion & & & $0.28^{\star \star}$ \\
\hline \multicolumn{4}{|l|}{ Current residence } \\
\hline Rural & 1.00 & 1.00 & 1.00 \\
\hline Urban & $0.47^{* *}$ & $0.47^{* *}$ & $0.45^{\star \star}$ \\
\hline \multicolumn{4}{|l|}{ Regions } \\
\hline Northeast & 1.00 & 1.00 & 1.00 \\
\hline North & $0.62^{* *}$ & $0.52^{\star *}$ & $0.54^{* *}$ \\
\hline Southeast & 0.97 & 0.95 & 0.95 \\
\hline South & 0.86 & 0.85 & 0.86 \\
\hline Midwest & 0.98 & 0.89 & 0.93 \\
\hline SES & 1.31 ** & 1.31 ** & $1.31^{\text {** }}$ \\
\hline $\mathrm{N}$ & 2,593 & & \\
\hline
\end{tabular}

Notes: **p-value $<0.05$; ${ }^{*}$-value $<0.1$

Source: PNDS 2006

Second, young Pentecostal women with high attendance showed a much higher odds of being in a formal union $(\mathrm{OR}=2.01$; $\mathrm{p}<0.05)$ compared to Catholics with the same religious attendance. Third, Pentecostals with low religious attendance had a much lower odds of being in a formal union $(\mathrm{OR}=0.43$; $\mathrm{p}<0.05)$ than Catholics with high attendance. This result can also suggest that: Pentecostals with low religious attendance at the time of interview may have stopped attending church after engaging in an informal conjugal union. Finally, when we compare Missionary Evangelicals and Catholics with the same religious attendance, the Missionary Evangelicals' higher odds of being in a formal union (observed in Model 4) disappeared. Therefore, attendance is 
important in the association between religion and the type of union chosen by young women.

The results of the other explanatory variables in Table 4 are similar to those in Table 3. However, three important differences should be highlighted. Black (as well as brown) women had a much higher odds ratio of being in an informal union than white women. Similarly, residents in urban areas and in the north had higher odds of being in an informal union compared to residents in rural areas and in the northeast, respectively.

\subsection{Attempting a causal inference}

The next table considers women who reported the same current religion as the religion in which they were raised (Table 5). As explained in the methods section, the analysis of this group may be much less contaminated by methodological problems arising from lack of information on the religion of the young women at the time of union because we assume that these young women have never changed religion. Model 7 considers this group, including women who were in a conjugal union for the first time and who were never in a union. The model shows that the odds of being in a union was statistically significant at $10 \%$ only for the Missionary Evangelicals $(\mathrm{OR}=1.50, \mathrm{p}<0.10)$, while the coefficient for Pentecostals was not statistically significant. This result partially contradicts hypothesis 7.

Table 5: Odds ratio of being in a union for the first time compared to never having been in a union (Model 7) and odds ratio of being in a formal union compared to an informal union (Model 8). Women between 20 and 29 years old who reported the same current religion as the religion in which they were raised. Brazil, 2006

\begin{tabular}{lll}
\hline Explanatory Variables & Model 7 & Model 8 \\
\hline Age & & \\
20 & 1.00 & 1.00 \\
21 & $2.14^{\star \star}$ & $4.60^{\star \star}$ \\
22 & $1.98^{\star \star}$ & 1.95 \\
23 & $1.95^{\star \star}$ & 1.97 \\
24 & $3.26^{\star \star}$ & $3.09^{\star \star}$ \\
25 & $3.15^{\star \star}$ & $3.64^{\star \star}$ \\
26 & $3.25^{\star \star}$ & $3.27^{\star \star}$ \\
\hline
\end{tabular}


Verona et al.: First conjugal union and religion

Table 5: (Continued)

\begin{tabular}{|c|c|c|}
\hline Explanatory Variables & Model 7 & Model 8 \\
\hline 27 & $5.25^{\star \star}$ & $5.05^{\star \star}$ \\
\hline 28 & $6.47^{\star *}$ & $5.83^{\star \star}$ \\
\hline 29 & $9.11^{\star *}$ & $4.07^{\star \star}$ \\
\hline \multicolumn{3}{|l|}{ Race } \\
\hline White & 1.00 & 1.00 \\
\hline Black & 0.97 & $0.47^{\star \star}$ \\
\hline Brown & $1.65^{\star \star}$ & $0.63^{*}$ \\
\hline Other color & 0.70 & 0.79 \\
\hline \multicolumn{3}{|l|}{ Years of formal education } \\
\hline 0 to 4 years & 1.00 & 1.00 \\
\hline 5 to 8 years & 1.22 & 1.23 \\
\hline 9 or more & $0.39 \star \star$ & $2.17^{\star \star}$ \\
\hline \multicolumn{3}{|l|}{ Religious affiliation } \\
\hline Catholic & 1.00 & 1.00 \\
\hline Missionary Evangelical & $1.50^{*}$ & $2.52^{\star \star}$ \\
\hline Pentecostal & 1.51 & $3.95^{\star \star}$ \\
\hline Other religion & 0.57 & 0.73 \\
\hline No religion & $0.35^{\star *}$ & $0.29^{*}$ \\
\hline \multicolumn{3}{|l|}{ Current residence } \\
\hline Rural & 1.00 & 1.00 \\
\hline Urban & 0.85 & $0.41^{\star \star}$ \\
\hline \multicolumn{3}{|l|}{ Regions } \\
\hline Northeast & 1.00 & 1.00 \\
\hline North & 1.33 & $0.52^{\star \star}$ \\
\hline Southeast & 1.14 & 0.99 \\
\hline South & $1.94^{\star \star}$ & 0.88 \\
\hline Midwest & $2.13^{\star \star}$ & 0.98 \\
\hline SES & $0.81^{\star \star}$ & $1.25^{\star \star}$ \\
\hline $\mathrm{N}$ & 3,099 & 1,970 \\
\hline
\end{tabular}

Notes: *^p-value $<0.05 ;{ }^{\star}$ p-value $<0.1$

Source: PNDS 2006

However, Model 8 shows that among those who had never changed their religion, Evangelicals' (Missionary and Pentecostal) odds of being in a formal union was far higher than that of Catholics. This result supports our hypothesis 7 and suggests that 
young Evangelical women, who supposedly have never changed religion, have stricter attitudes towards informal union than the total group of Evangelical women between 20 and 29 years old (including women who reported a current religion that differed from the religion in which they were raised).

In general, the results from Models 7 and 8 may help provide evidence to support the causal direction emphasized in this paper; that is, the effect of religion on decisions about the timing and type of union in Brazil.

\section{Summary and discussion}

The objective of this work was to analyze the association between religion and two variables of female conjugal regime in Brazil: entry into first union and type of union. The age group of 20 to 29 years old was used in the analysis because a significant proportion of women in this age group had experienced their first union in Brazil in 2006. Although cross-sectional in nature, the data from the PNDS 2006 allowed us to analyze the odds of experiencing a first union because the questionnaire asks whether the woman has been in a union one or more times. Unlike most studies on marriage in Brazil, the current results enable the examination of characteristics of the conjugal regime while taking into account the initial trajectory of the woman's marital life. This is an important contribution of the current study.

Most countries in Latin America exhibit an earlier-than-expected age at first union. Compared with other countries in the continent, Brazil has a late average age at union formation. However, this age is early compared to developed countries and when taking into consideration its income level and low fertility. The informal union, which has existed in Brazil since the country was established, has grown significantly and has recently been associated with the secularization process (Esteve, Lesthaeghe, and Lopez-Gay 2012). Undoubtedly, both conjugal union variables studied in this work are discussed in the Brazilian religious field. Nevertheless, in the academic literature, studies of the associations between religion and these variables using Brazilian demographic data are scarce or nearly nonexistent. One contribution to this gap is Miranda-Ribeiro, Longo, and Marteleto's (2010) study.

The main results of this study show that religion (measured by religious affiliation and attendance) has a strong association with entry into first union and type of union established by women in Brazil. The total group of Evangelical women (including women who reported a current religion that differed from the religion in which they were raised) presents much higher odds of being in a union for the first time (suggesting early age at the time of union) and of preferring a formal union, compared to Catholics. Results for the association of union formation variables and the interaction between 
religious affiliation and attendance are similar. Pentecostal women with high attendance at worship services, for example, had much higher odds of being in a first union and of preferring a formal marriage than Catholics with the same attendance.

These outcomes contradict a common finding in the literature on conjugal union in Latin American countries that identifies an association between the timing of the union and the type of union chosen. That is, previous studies have suggested that women in early unions prefer an informal union (Rosero-Bixby 1996; Fussell and Palloni 2004; Vignoli 2005). Evangelical women aged 20 to 29 years in Brazil do not display this behavior. Rather, they enter a union relatively early and prefer a formal union. This result is intriguing and should be considered in studies of conjugal unions in the Brazilian context. Among other reasons, it is important to mention the growing number of Evangelicals (mainly Pentecostals) in the country, as these accounted for over onefifth of the Brazilian population (22.2\% of the total) in 2010.

Nevertheless, it is important to state that because of the cross-sectional nature of the PNDS data, it is not possible to know the temporal ordering of the events or the causality direction of the relationship between religion and first conjugal union and type of union. This research tried to infer it by estimating odds ratios only for women who reported the same current religion as the religion in which they were raised. These results suggest that religion does not affect first conjugal union in Brazil. However, it does influence type of union.

Religion acts on family formation through several mechanisms (Eggebeen and Dew 2009; McQuillan 2004; Smith 2003). This study emphasizes the role of the rules concerning behavior and lifestyle highlighted by Pentecostal churches and the role of these churches in building family ties. Our results on the association between the age at first conjugal union and Evangelical groups corroborate the theoretical approach suggested by Fussell and Paloni (2004). According to these authors, the formation of family ties (which can occur through religious involvement) helps to explain the earliness of the average age at union formation observed in recent decades in Latin America.

It is important to highlight that family ties may act in different ways. They can support, for instance, motherhood without conjugal union, suggesting that the function of the family does not imply an early marriage. Family support is especially important to teenage mothers and has been found to have a positive influence on parenting behaviors (Bunting and McAuley 2004). It can be of special importance in Brazil, where both rates of motherhood without conjugal union and adolescent fertility remain high (Vignoli and Cavenaghi 2014).

Esteve, Lesthaeghe, and Lopez-Gay (2012) recently suggested the possibility of secularization being an explanation for the cohabitation boom in Latin America in recent decades. Our results indicate that this suggestion should be considered carefully 
when the Brazilian context is analyzed. The recent religious landscape in Brazil shows a significant advance of Evangelicals. This movement emphasizes rules and values that disapprove of informal marriage, and offers opportunities for the building and intensification of social and family ties. Thus, even in the context of a growing proportion of informal conjugal unions in Brazil, the Evangelical movement may be inhibiting the increase, which otherwise would be even greater.

Finally, the results of this study contribute to the discussion on the potential signs of the Second Demographic Transition (SDT) in Brazil. The two features observed among Evangelical women, early and formal conjugal union, are aspects that inhibit or delay the diffusion of the conjugal pattern this approach suggests. Much will depend on the continuation of religious changes in the country and on the strength of the churches' mechanisms of influence.

In addition, the onset or diffusion of the SDT in the country might vary according to Evangelicals' socioeconomic and demographic profile. The most likely pioneers of the SDT are the younger and better-educated groups. As mentioned above, Pentecostalism emerged and grew among the poor and remains the religious group with the lowest education and income levels in the country. Nevertheless, changes may have been taking place. For instance, in 2010 14.4\% of Pentecostal women aged 25-29 reported having completed some college , and, when the three segments of Evangelicals are taken together, one fifth of Evangelical women between 25 and 29 years had more than complete secondary education.

Finally, concomitantly with the discussion on the (lack of) potential signs of the SDT in Brazil, the results of this study confirm its assumption that religion (or secularization) is very important in decisions about union formation.

\section{Acknowledgments}

The authors would like to thank Fapemig (Fundação de Amparo à Pesquisa de Minas Gerais - Edital 15/2010) and CNPq (Conselho Nacional de Desenvolvimento Científico e Tecnológico - Edital 07/2011) for financially support this research project. 
Verona et al.: First conjugal union and religion

\section{References}

Acosta, F. (2003). La familia en los estudios de población en América Latina: estado del conocimiento y necesidades de investigación. Papeles de Población 9(37): 9-50.

Alves, J.E.D., Barros, L.F.W., and Cavenaghi, S. (2012). A dinâmica das filiações religiosas no Brasil entre 2000 e 2010: diversificação e processo de mudança de hegemonia. Rever 2(12): 145-174.

Bruneau, T.C. (1982). The church in Brazil - The politics of religion. Austin: University of Texas Press.

Bunting, L. and McAuley, C. (2004). Research Review: Teenage pregnancy and motherhood: the contribution of support. Child \& Family Social Work 9: 207215. doi:10.1111/j.1365-2206.2004.00335.x.

Burdick, J. (1993). Looking for god in Brazil. Berkeley: University of California Press.

Castro Martin, T. (2002). Consensual unions in Latin America: Persistence of a dual nuptiality system. Journal of Comparative Family Studies 33(1): 35-55.

Cavenaghi, S.M. (2009a). Aspectos metodológicos e comparabilidade com pesquisas anteriores. In: BRASIL, Ministério da Saúde e Cebrap (eds.). Pesquisa Nacional de Demografia e Saúde da Criança e da Mulher PNDS 2006: dimensões do processo reprodutivo e da saúde da criança. Brasília: Ministério da Saúde:1332.

Cavenaghi, S.M. (2009b). Perfil dos domicílios e das famílias. In: BRASIL, Ministério da Saúde e Cebrap (eds.). Pesquisa Nacional de Demografia e Saúde da Criança e da Mulher PNDS 2006: dimensões do processo reprodutivo e da saúde da criança. Brasília: Ministério da Saúde: 33-54.

Chesnut, R.A. (2003). Competitive spirits - Latin America's new religious economy. New York: Oxford University Press.

Cleary, E.L. (2007). The Catholic Charismatic renewal: revitalization movements and conversion. In: Steigenga T.J. and Cleary E.L. (eds.). Conversion of a continent: Contemporary religious change in Latin America. New Brunswick: Rutgers University Press: 153-173.

Covre-Sussai, M., Meuleman, B., Botterman, S., and Matthijs, K. (2015). Traditional and modern cohabitation in Latin America: A comparative typology. Demographic Research 32(32): 873-914. doi:10.4054/DemRes.2015.32.32. 
DeMaris, A., Mahoney, A., and Pargament, K.I. (2011). Doing the scut work of infant care: Does religiousness encourage father involvement? Journal of Marriage and Family 73(2): 354-368. doi:10.1111/j.1741-3737.2010.00811.x.

Eggebeen, D. and Dew, J. (2009). The role of religion in adolescence for family formation in young adulthood. Journal of Marriage and Family 71(1): 108-121. doi:10.1111/j.1741-3737.2008.00583.x.

Esteve, A., Garcia-Roman, J., Lesthaeghe, R., and Lopez-Gay, A. (2012). The "Second Demographic Transition" Features in Latin America: the 2010 Update [unpublished manuscript]. Barcelona: Centre d'Estudis Demogràfics.

Esteve, A., Lesthaeghe, R., and López-Gay, A. (2012). The Latin American Cohabitation Boom, 1970-2007. Population and Development Review 38(1): 55-82. doi:10.1111/j.1728-4457.2012.00472.x.

Esteve, A., López-Ruiz, L., and Spijker, J. (2013). Disentangling how educational expansion did not increase women's age at union formation in Latin America from 1970 to 2000. Demographic Research 28(3):63-76. doi:10.4054/DemRes. 2013.28.3.

Fussell, E. and Palloni, A. (2004). Persistent marriage regimes in changing times. Journal of Marriage and Family 66(5): 1201-1213. doi:10.1111/j.0022-2445. 2004.00087.x.

García, B. and Rojas, O. (2002). Cambio en la formación y disoluciones de las uniones en América Latina. Papeles de Población 8(32): 12-31.

Heaton, T., Forste, R., and Otterstrom, S. (2002). Family transitions in Latin America: First intercourse, first union and first birth. International Journal of Population Geography 8(1): 1-15. doi:10.1002/ijpg.234.

Hill, Z., Cleland, J., and Ali, M. (2004). Religious affiliation and extramarital sex among men in Brazil. International Family Planning Perspectives 30(1): 20-26. doi:10.1363/3002004.

Lesthaegue, R. (2010). The unfolding story of the Second Demographic Transition. Population and Development Review 36(2): 211-251. doi:10.1111/j.1728-4457. 2010.00328.x.

Mariano, R. (2013). Mudanças no campo religioso brasileiro no censo 2010. Debates do NER 14(24): 119-137.

Mariz, C. (1994). Coping with poverty: Pentecostal and Christian base communities in Brazil. Philadelphia: Temple University Press. 
Verona et al.: First conjugal union and religion

McKinnon, S., Potter, J., and Garrard-Burnett, V. (2008). Adolescent fertility and religion in Rio de Janeiro, Brazil in the year 2000: the role of Protestantism. Population Studies 62(3): 289-303. doi:10.1080/00324720802349086.

McQuillan, K. (2004). When does religion influence fertility? Population and Development Review 30(1): 25-56. doi:10.1111/j.1728-4457.2004.00002.x.

Miranda-Ribeiro, P., Longo, L., and Marteleto, L. (2010). What's God got to do with it? Religion, religiosity, and union formation among women in Brazil. Poster presented at the 2010 Population of Association of America Meeting. Dallas. TX, April 15-17 2010.

Ogland, C. and Verona, A.P.A. (2011) . Religion and attitudes towards abortion and abortion policy in Brazil. Journal for the Scientific Study of Religion 50(4): 812821. doi:10.1111/j.1468-5906.2011.01602.x.

Pesquisa Nacional de Demografia e Saúde da Criança e da Mulher - PNDS 2006 (2009). Dimensões do processo reprodutivo e da saúde da criança/ Ministério da Saúde. Centro Brasileiro de Análise e Planejamento.

Pierucci, A.F.O. and Prandi, R. (2000). Religious diversity in Brazil: Numbers and perspectives in a sociological evaluation. International Sociology 15(4): 629639. doi:10.1177/0268580900015004004.

Rosero-Bixby, L. (1996). Nuptiality trends and fertility transition in Latin America. In: Guzmán, J.M., Singh, S., Rodríguez, G. and Pantelides, E. (eds). The fertility transition in Latin America. Oxford: Oxford University Press: 135-150.

Smith, C. (2003). Theorizing religious effects among American adolescents. Journal for the Scientific Study of Religion 42(1): 17-30. doi:10.1111/1468-5906.t01-100158.

Vaaler, M.L., Ellison, C., and Powers, D. (2009). Religious influence on the risk of marital dissolution. Journal of Marriage and Family. 71(4): 917-934. doi:10.1111/j.1741-3737.2009.00644.x.

Verona, A.P.A. (2010). Sexual Initiation and Religion in Brazil [PhD Thesis]. Austin: The University of Texas at Austin: Department of Sociology.

Verona, A.P.A. (2011). Explanations for religious influence on adolescent sexual behavior in Brazil: direct and indirect effects. Revista Brasileira de Estudos da População 28(1): 187-201. doi:10.1590/S0102-30982011000100010. 
Verona, A.P.A. and Dias, Jr.C.S. (2012). Religião e fecundidade entre adolescentes no Brasil. Revista Panamericana de Salud Pública 31(1): 25-31. doi:10.1590/ S1020-49892012000100004.

Verona, A.P.A. and Regnerus, M.D. (2014). Pentecostalism and sexual initiation in Brazil. Revista Brasileira de Estudos da População 31(1): 99-115. doi:10.1590/ S0102-30982014000100006.

Vignoli, J.R. (2005). Union y cohabitacion en America Latina: Modernidad, exclusion, diversidad? Chile: CELADE, Serie Poblacion y Desarrollo 57.

Vignoli, J.R. and Cavenaghi, S. (2014). Adolescent and youth fertility and social inequality in Latin America and the Caribbean: what role has education played? Genus 70(1): 1-25.

Wilcox, B.L., Rostosky, S.S., Randall, B., and Wright, M.L.C. (2001). Reasons for hope: A review of research on adolescent religiosity and sexual behavior. In: Whitehead, B.D., Wilcox, B.L., and Rostosky, S.S. (eds.). Keeping the faith: The role of religion and faith communities in preventing teen pregnancy. Washington, DC: The National Campaign to Prevent Teen Pregnancy: 31-82. 
Verona et al.: First conjugal union and religion 